\title{
"I know, therefore I adapt?" Complexities of individual adaptation to climate-induced forest dieback in Alaska
}

\author{
Lauren E. Oakes $^{1}$, Nicole M. Ardoin ${ }^{2}$ and Eric F. Lambin ${ }^{3,4}$
}

\begin{abstract}
Individual actions to avoid, benefit from, or cope with climate change impacts partly shape adaptation; much research on adaptation has focused at the systems level, overlooking drivers of individual responses. Theoretical frameworks and empirical studies of environmental behavior identify a complex web of cognitive, affective, and evaluative factors that motivate stewardship. We explore the relationship between knowledge of, and adaptation to, widespread, climate-induced tree mortality to understand the cognitive (i.e., knowledge and learning), affective (i.e., attitudes and place attachment), and evaluative (i.e., use values) factors that influence how individuals respond to climate-change impacts. From 43 semistructured interviews with forest managers and users in a temperate forest, we identified distinct responses to local, climate-induced environmental changes that we then categorized as either behavioral or psychological adaptations. Interviewees developed a depth of knowledge about the dieback through a combination of direct, place-based experiences and indirect, mediated learning through social interactions. Knowing that the dieback was associated with climate change led to different adaptive responses among the interviewees, although knowledge alone did not explain this variation. Forest users reported psychological adaptations to process negative attitudes; these adaptations were spurred by knowledge of the causes, losses of intangible values, and impacts to a species to which they held attachment. Behavioral adaptations exclusive to a high level of knowledge included actions such as using the forests to educate others or changing transportation behaviors to reduce personal energy consumption. Managers integrated awareness of the dieback and its dynamics across spatial scales into current management objectives. Our findings suggest that adaptive management may occur from the bottom up, as individual managers implement new practices in advance of policies. As knowledge of climate-change impacts in local environments increases, resource users may benefit from programs and educational interventions that facilitate coping strategies.
\end{abstract}

Key Words: attitudes; climate change; forest management; individual adaptation; knowledge; place attachment; use values

\section{INTRODUCTION}

Unprecedented rates of global environmental change require understanding the modifications of the natural environment, as well as human responses to these changes that, together, influence the vulnerability of people and places (Lambin et al. 2006, Turner et al. 2007, Rounsevell et al. 2012). Continued increases in greenhouse gas emissions mean social-ecological systems must now adapt to climate-change impacts (Benson and Craig 2014). This involves cascading decisions that span from individuals to civil society and governments (Adger et al. 2005). Improving understanding of how resource users and managers respond to changes in their local environment is important as people confront these impacts.

In the climate sphere, scientists and policymakers define adaptation as "adjustments in natural or human systems in response to actual or expected climatic stimuli and their effects" (Parry et al. 2007:6). In the human dimensions of environmental change, adaptation refers to a process, action, or outcome of a system (e.g., community or region) in which the system can "better cope with, manage or adjust" to changing conditions (Smit and Wandel 2006:282). Adaptation research has focused primarily on systems, with less attention to the individual actors that comprise them and act on behalf of themselves and society (Adger 2003, Grothmann and Patt 2005). Individuals have adapted to changes in climate throughout human history, but the effectiveness of societies to adapt to increasing rates of change depends, in part, on the collective responses emerging from individual adaptations (Adger 2003, Folke 2006). These may occur through behavioral changes to better suit the environment or through psychological responses (Reser and Swim 2011, Swim et al. 2011).

Although knowledge (i.e., the understanding about a subject acquired through experience or education) about climate change and its impacts is "one important prerequisite that facilitates the adjustment to new conditions" (Sundblad et al. 2009:281), it may not lead to desired outcomes (Kollmuss and Agyeman 2002, Heimlich and Ardoin 2008). Becoming engaged in adaptation requires people to care about the changes occurring, feel motivated, and have the ability to act (Lorenzoni et al. 2007, Wolf and Moser 2011). Adaptation scholars are beginning to draw from the literature on environmental behavior to explore how the cognitive, affective, and evaluative factors that motivate proenvironmental behavior may apply to individual adaptive responses to climate change (Adger et al. 2012).

Diverse theoretical frameworks and empirical studies address gaps between individuals' environmental knowledge and proenvironmental behaviors. Early models were based on the assumption of a linear progression of environmental knowledge leading to concern (an environmental attitude, or way of thinking or feeling about the environment or an issue), which was assumed to lead to proenvironmental behavior (e.g., as demonstrated by Ramsey and Rickson 1976, Birch and Schwaab 1983). Subsequent

\footnotetext{
${ }^{1}$ Emmett Interdisciplinary Program in Environment and Resources, Stanford University, ${ }^{2}$ Graduate School of Education and Woods Institute for the Environment, Stanford University, ${ }^{3}$ School of Earth, Energy, and Environmental Sciences, Stanford University, ${ }^{4}$ Woods Institute for the Environment, Stanford University
} 
research highlighted the discrepancy, and lack of a direct line, between proenvironmental attitudes and behaviors (Hines et al. 1987, Kollmuss and Agyeman 2002, Heimlich and Ardoin 2008). Cognitive processes, for example, contribute to developing, and continually practicing, new behaviors as individuals observe others' behaviors (Bandura 1977a, 1977b). Active learning (Fonseca and Chi 2011) about the environment directly (e.g., through personal, firsthand, place-based experience), rather than indirectly (e.g., through in-school settings or social networks), may encourage a stronger, more direct relationship between attitudes and behaviors (Rajecki 1982, Finger 1994, Ballard and Belsky 2010). The degree to which individuals see themselves as part of the natural world relates to the type of concern an individual develops for an issue, and the situations that motivate them to act. Concern often intertwines with other drivers, such as place attachment and the use values an individual derives from a resource, to motivate proenvironmental behaviors (Schultz 2000, 2001, 2002, Schultz et al. 2004).

Place attachment, a suite of place-related emotions that binds someone to a geographic location (Rubinstein and Parmelee 1992), develops based on a variety of factors, such as residency, shared social experiences, and place-related learning (Vaughan and Ardoin 2014). This attachment can form functionally when a resource provides amenities necessary for desired activities (Stokols and Shumaker 1981, Williams and Roggenbuck 1989, Williams and Vaske 2003), or emotionally when psychological investment in a setting or resource develops through experience over time (Kals et al. 1999, Williams and Patterson 1999, Rogan et al. 2005, Scannell and Gifford 2010). Attachment tends to increase an individual's willingness to protect or conserve the place, or source, of attachment (Vaske and Kobrin 2001, Ardoin 2006, Devine-Wright 2009, Russell et al. 2013). It is often associated with use values, or the benefits that a resource provides for those who use it, both directly, i.e., through extractive or nonextractive uses, such as tourism and recreation, or indirectly, i.e., through intangibles values, such as aesthetic appreciation or spiritual value (Kellert 1996, 1997, Gee and Burkhard 2010).

These cognitive, affective, and evaluative variables mediate and moderate people's environmental interactions and may apply to individual-level adaptation. A sense of attachment to the changing ecosystem or its components may help explain varying responses to climate-change impacts as values and culture shape adaptation (Adger et al. 2009, 2012). Few empirical studies provide evidence of how these factors influence individual, adaptive responses to a climate-change-impacted system. A persistent gap remains between concern and attitudes about climate-change impacts and climate-related behaviors (Moser 2014), which may be due, in part, to learning about climate change through sensationalist messaging (e.g., dramatic glacial retreat), as opposed to through knowledge of the local impacts that occur in communities across the planet (Otieno et al. 2014). Wibeck (2014) identified problems with the "information deficit model," recognizing that knowledge alone is insufficient to engage citizens in climate-related issues. Fritze et al. (2008) argued that understanding the extent of short-term and long-term challenges posed by climate change can create distress and affect citizens' responses. In contrast, research suggests correlations between feelings of hope and efficacy, and a willingness to engage in proenvironmental behaviors and support climate change policies
(Lorenzoni et al. 2007). Our review of the adaptation literature indicates a dearth of empirical studies that have explored how these factors interact with one another to shape individual responses to local climate-change-induced impacts.

The objective of our study is to investigate the relationship between knowledge of, and adaptation to, widespread, climateinduced tree mortality to better understand the cognitive (i.e., knowledge and learning), affective (i.e., attitudes and place attachment), and evaluative (i.e., use values) factors that affect how resource users and managers respond to local climate-change impacts. Our study takes place in the Alexander Archipelago of southeastern Alaska, which, together with the Pacific Northwest coast, retains the largest collective area of temperate rainforests on Earth (Kellogg 1992, DellaSala et al. 2011). We explored how individuals learn about impacts occurring locally and if knowing that these impacts are climate-change-related influences their responses to the impacts. We expected to find different adaptive responses between participants who were knowledgeable about the dieback's causal link to climate change, compared to those who were not. We also anticipated that other factors known to motivate environmentally responsible behavior, such as concern, place attachment, and the use values people derive from nature, would help explain any observed variations. Based on the environmental behavior literature, our hypotheses focused primarily on adaptation as changes in individuals' actions, but study participants also highlighted a suite of psychological adaptations.

\section{MATERIALS AND METHODS}

\section{Study background}

Referred to as "yellow-cedar decline," the extensive mortality of yellow-cedar [Callitropsis nootkatensis (D. Don) Oersted ex D.P. Little] covers nearly 200,000 hectares (Lamb and Winton 2011, Hennon et al. 2012) in southeast Alaska and extends further into British Columbia (Westfall and Ebata 2014). Research links the dieback to climate change; reduced snowpack makes the shallow roots of these trees vulnerable to sudden cold weather (Schaberg et al. 2005, 2008, 2011, D'Amore and Hennon 2006, Beier et al. 2008, Hennon et al. 2012). The decline occurs on designated wilderness lands in southeast Alaska, as well as lands managed for timber and other uses in the Tongass National Forest (Tongass), which comprises approximately $80 \%$ of the archipelago (Albert and Schoen 2013). This dieback is not unique; researchers have documented widespread, climate-induced forest dieback events across the globe, and they are expected to increase with warming temperatures (Allen and Breshears 2007, Allen et al. 2010). Changes in forest structure and function related to climate have regional societal consequences (Flint 2006, Chapin et al. 2008, Trainor et al. 2009, Wolken et al. 2011). Both social and ecological aspects of the decline (Appendix 1) provide an opportunity to explore linkages between knowledge and adaptation, as well as other factors motivating individual responses to climate-change-induced impacts.

\section{Interview protocol}

The lead author conducted interviews with forest users $(n=34)$ and managers $(n=11)$ during 2013; responses from two forest users, who were unaware of the dieback, were removed from the final dataset $(\mathrm{N}=43)$ for analyses. Formal and informal 
interactions with forest users, managers, and community members informed the semistructured interview protocol design (Patton 2002). Based on Ostrom's (2009) framework for analyzing social-ecological systems, we defined "users" as individuals who use the forest in diverse ways, and "managers" as those who work within the Tongass or manage Alaska Native land. The interview protocol (Appendix 1) included questions covering four lines of inquiry: (1) How knowledgeable are users and managers about forests affected by yellow-cedar decline, and how are they learning about the dieback? (2) What are forest users' attitudes about these changing forests? (3) What kinds of use values do users and managers associate with yellow-cedar forests, and what impact does the dieback have on those use values? (4) In what ways, if any, are forest users and managers adapting to the changes occurring in these affected forests? Our narrative-style interview approach allowed individual perspectives and experiences to emerge and enabled collection of qualitative data (Patton 2002) that elucidated a range of use values not often captured in standardized, direct question-answer techniques (Satterfield 2001, Gould et al. 2015; Appendix 1).

\section{Sampling frame and characteristics}

Interviews were conducted with adult Alaska residents (minimum of one year of residency) living in towns and remote places predominantly within the northern portion of the yellow-cedar population distribution in the Alexander Archipelago (Fig. 1). This geographic restriction prevented participant confusion between yellow-cedar and western red cedar (Thuja plicata Donn ex D. Don), a similar species found in the southern extent of the archipelago. We identified five towns (Juneau, Sitka, Hoonah, Tenakee Springs, and Gustavus) for interviewing, based on proximity to live yellow-cedar forests and forests affected by the dieback and the ability to sample forest users and managers who represented a diversity of forest resource uses. To enable broader participation of individuals active in forest management and forest industry, we included residents outside these primary locations whose professional work or use of forest resources extended to the northern Tongass.

We selected participants using a mixed-purposeful strategy, combining chain-referral and intensity sampling (Patton 2002). In addition to individuals directly using the forests, we identified forest managers working at the Regional Native Corporation and federally recognized tribal governments, and at various institutional levels (e.g., district, regional) within the USDA Forest Service. We determined participant categories (Table 1) a priori by reviewing regional forest management documents (USDA-FS 2008) and publicly available information (e.g., local news, government websites) on organizations, agencies, and companies involved in forest-related issues. To affirm, or refine, these a priori classifications, we asked interviewees to indicate how they self-identified (Appendix 1) as users or managers within the categories specified.

\section{Data analysis}

We transcribed the interviews verbatim; we analyzed the data by combining targeted and open coding processes (Maxwell 2005, Creswell 2012) using NVivo 10.0 (QSR International) for explanatory variables (Appendix 1). Targeted or selective coding involves combing data for mentions of predetermined themes; open coding entails analyzing with allowance for emergent themes and patterns (Glaser 1992). The authors and two assistants developed the coding iteratively. Interviewees were classified to emergent-knowledge groupings based upon their awareness of the dieback and knowledge of its causes. We then identified adaptive responses that emerged from the participants and assigned them to broader categories, or "forms" of adaptation.

Fig. 1. Residency locations in southeast Alaska for study participants (n) with yellow-cedar decline (USDA-FS 2010) and distribution (Hennon et al. 2015). Dashed line indicates current northern limit of western red cedar distribution.

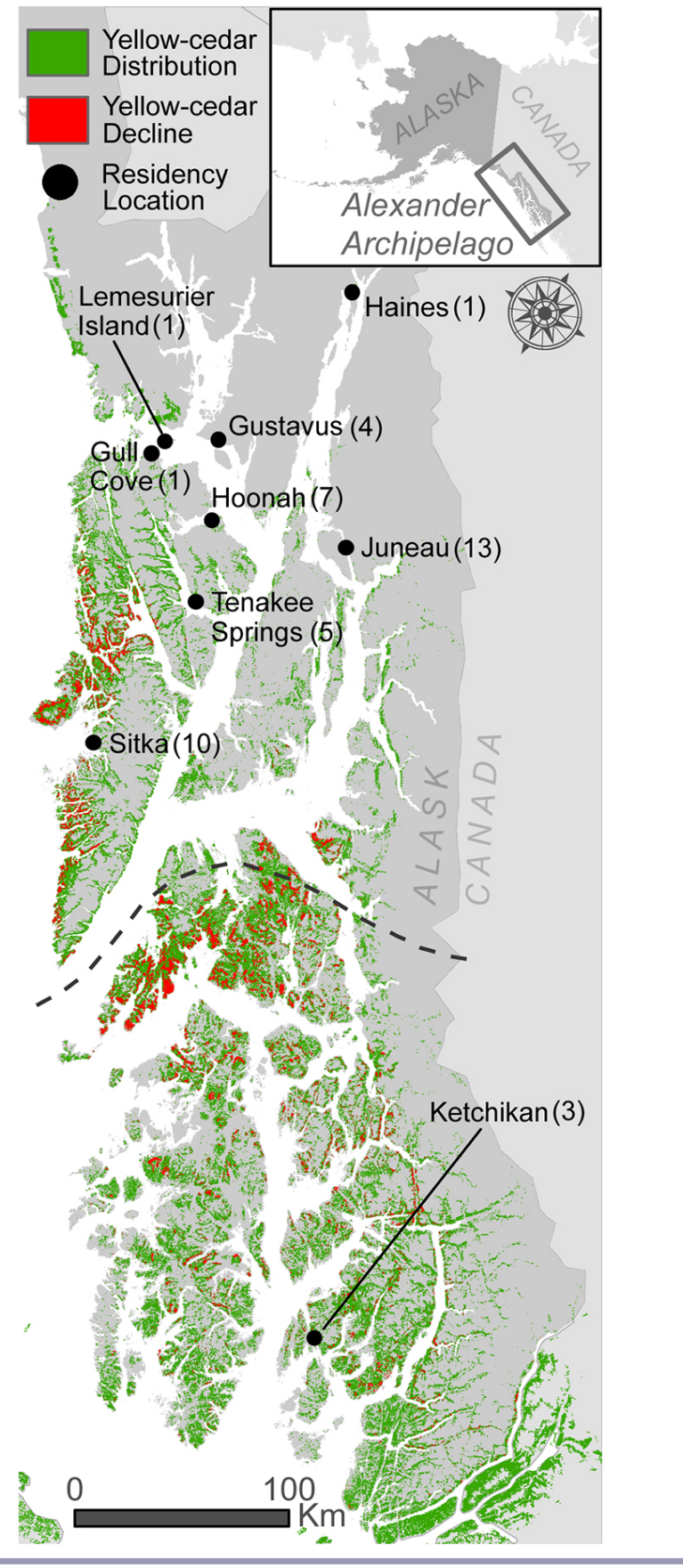


Table 2. Adaptations that emerged from study participants.

\begin{tabular}{|c|c|c|c|c|}
\hline Adaptation type & Form & Definition & $\begin{array}{l}\text { Reported activities or evidence of adaptive } \\
\text { form }\end{array}$ & $\begin{array}{l}\text { Scale of } \\
\text { intended } \\
\text { outcomes }^{\dagger}\end{array}$ \\
\hline \multirow[t]{9}{*}{ Behavioral } & Educating & $\begin{array}{l}\text { Integrating dieback knowledge into } \\
\text { public education efforts or educating } \\
\text { others in informal settings }\end{array}$ & $\begin{array}{l}\text { Giving talks about the dieback and its causes; } \\
\text { conducting workshops related to potential } \\
\text { harvest of dead trees }\end{array}$ & $\begin{array}{l}\text { Local, regional, } \\
\text { global }\end{array}$ \\
\hline & Favoring or promoting & $\begin{array}{l}\text { Integrating dieback knowledge into } \\
\text { professional practices }\end{array}$ & $\begin{array}{l}\text { Selecting stressed trees for commercial } \\
\text { harvest; integrating knowledge of the dieback } \\
\text { (site conditions) into operational planting }\end{array}$ & Local, regional \\
\hline & Opportunistically using & $\begin{array}{l}\text { Exploiting new opportunities by } \\
\text { chance or circumstance; creating new } \\
\text { uses for dead trees or affected forests }\end{array}$ & $\begin{array}{l}\text { Hunting in affected forests, harvesting dead } \\
\text { trees for firewood, selecting dead trees for } \\
\text { specific wood projects, using affected forests } \\
\text { for education about global climate change } \\
\text { when tour boat route permits }\end{array}$ & Local, global \\
\hline & Physically avoiding & $\begin{array}{l}\text { Actively averting dead trees or affected } \\
\text { forests; changing locations for land use } \\
\text { to forests where the dieback is less } \\
\text { likely to be encountered }\end{array}$ & $\begin{array}{l}\text { Intentionally avoiding experience in, use of, } \\
\text { or exposure to, dead trees or affected forests }\end{array}$ & Local \\
\hline & Preferentially using & $\begin{array}{l}\text { Actively choosing to use live trees or } \\
\text { affected forests instead of unaffected }\end{array}$ & Preferentially seeking out dead trees & Local \\
\hline & Researching & $\begin{array}{l}\text { Studying ecological dynamics related to } \\
\text { dieback }\end{array}$ & $\begin{array}{l}\text { Initiating or participating in experimental } \\
\text { plantings }\end{array}$ & Local, regional \\
\hline & Restraining & $\begin{array}{l}\text { Actively refraining from actions that } \\
\text { affect the population or contribute to } \\
\text { climate change }\end{array}$ & $\begin{array}{l}\text { Limiting personal use of live trees or } \\
\text { unaffected forests; reducing individual energy } \\
\text { consumption by various avenues (e.g., biking } \\
\text { to work) }\end{array}$ & Local, global \\
\hline & Site-specific stewarding & $\begin{array}{l}\text { Protecting specific yellow-cedar trees or } \\
\text { unaffected forests, or creating } \\
\text { conditions more likely to promote tree } \\
\text { health }\end{array}$ & Piling snow at base of yellow-cedar trees & Local \\
\hline & Substituting & $\begin{array}{l}\text { Interchanging use values for live and } \\
\text { dead yellow-cedar trees or unaffected } \\
\text { and affected forests; replacing yellow- } \\
\text { cedar use with other species }\end{array}$ & $\begin{array}{l}\text { Using dead or live trees for similar forest } \\
\text { products; using western hemlock (Tsuga } \\
\text { heterophylla) or western red cedar (Thuja } \\
\text { plicata) instead of yellow-cedar }\end{array}$ & Local \\
\hline \multirow[t]{3}{*}{ Psychological } & Connecting & $\begin{array}{l}\text { Coping by focusing on importance of } \\
\text { repairing human-environment } \\
\text { relationships or connecting to each } \\
\text { other and place }\end{array}$ & $\begin{array}{l}\text { Stressing growing disconnect between } \\
\text { humans and environment as central problem } \\
\text { and source of occurring impacts; engaging } \\
\text { with other people to facilitate human-nature } \\
\text { interactions and understanding of } \\
\text { environmental change in informal settings }\end{array}$ & Self, others \\
\hline & $\begin{array}{l}\text { Expanding perspective } \\
\text { spatially and temporally }\end{array}$ & $\begin{array}{l}\text { Broadening spatial and temporal } \\
\text { perspective of forests }\end{array}$ & $\begin{array}{l}\text { Identifying a vast spatial and/or temporal } \\
\text { view of forests to counteract short-term and/ } \\
\text { or localized losses with long-term and/or } \\
\text { range-wide change; perceiving and accepting } \\
\text { dynamic forest }\end{array}$ & $\begin{array}{l}\text { Self, yellow- } \\
\text { cedar species }\end{array}$ \\
\hline & Grief processing & $\begin{array}{l}\text { Experiencing active healing process; } \\
\text { coping with loss }\end{array}$ & $\begin{array}{l}\text { Mourning losses of live trees and/or } \\
\text { unaffected forests }\end{array}$ & Self, others \\
\hline
\end{tabular}

Refers to the geographic scope of the adaptation as discussed by participants (e.g., limiting personal use locally or stressing the global disconnect between humans and the environment).

whereas broad-scale interactions, such as boating, influenced a deeper understanding of dieback's extent. Forest users who vicariously learned about the dieback through media networks reported less knowledge or no awareness of the causal link to climate change (groups one and two, above) than those who learned more actively, or in a personal way, by attending public presentations, seeking out published studies, or engaging in discussions with community members. Those most knowledgeable about the causal link to climate change tended to learn through a combination of indirect learning experiences (i.e., news media, published studies, or community members), as well as direct experience in place (i.e., their own firsthand observations and ecological understanding).
Focusing on their management objectives, managers were less occupied with obtaining a depth of understanding about climate change mechanisms than with the population dynamics that occur across the species range, or about present and future site conditions favorable to yellow-cedar.

As one manager explained:

I'm aware that there's concern that [yellow-cedar] is in decline as a species, and there's some theories, climate change being one of them, about the cause. I'm not really convinced that we know why it's happening...but maybe that's not even relevant. 


\section{Relationships between knowledge and adaptation}

The various forms of adaptation adopted by interviewees $(N=$ 43) differed significantly across knowledge groupings (PERMANOVA: $F=2.2277, p=0.02$ ) and between users and managers $(F=8.0184, p=0.001)$. Knowing that the environmental changes occurring were associated with climate change led interviewees to different adaptive responses. There was no statistically significant difference between the composition of forms adopted by interviewees in groups two and three $(F=$ $1.8543, p=0.075$ ). The qualitative data, however, indicated that an increase in knowledge was associated with specific responses; the intended outcomes of specific activities (behavioral) and psychological responses differed in scale; the saliency of responses, specifically for psychological forms of adaptation, also varied. We first report these qualitative findings from the interview data to explain the relationship between knowledge and adaptation, and then explain how secondary affective and evaluative factors shape reported adaptations.

Behavioral adaptations varied in the geographic scale of their intended outcomes, both across knowledge groupings and between users and managers. Users who were not aware of the dieback's link to climate change discussed specific behavioral responses with outcomes at local and regional scales (e.g., changing locations for recreational land use to avoid affected forests; opportunistically harvesting dead trees). Managers focused on integrating awareness of the dieback and knowledge of changing conditions into existing practices, such as planting trees where they may be more likely to survive in operational planting. In some cases, managers exercising these behavioral adaptations (e.g., favoring and promoting, researching; Table 2) clarified that these actions were not a direct response to climate change, but rather were an effort to incorporate awareness of the dieback and its dynamics across spatial scales into management objectives. Adaptive practices emerged as conscious efforts (e.g., behavioral changes in existing planting programs) "to move [the species] up [in elevation] and north to north-facing slopes on wellproductive sites," as one manager explained.

Reported forms of behavioral adaptation that were exclusive to group three included: site-specific stewarding (i.e., piling snow at the base of yellow-cedar trees), educating others about climate impacts by using yellow-cedar as an example, and adopting new transportation behaviors, such as biking to work, to reduce energy consumption. Individuals who adopted these behaviors acknowledged the global nature of climate change and reported a suite of behavioral adaptations intended to make some difference across multiple geographic scales. Irrespective of knowledge groupings, opportunistic use of dead trees was reported most commonly (28 interviewees). Although substitutions (i.e., dead for live, or other species for yellow-cedar), preferential uses, and restraining from using live trees were common behavioral adaptations for all knowledge groupings, those who were aware of the causal mechanism to climate change felt these types of behavioral changes allowed them to act responsibly.

One user explained:

The cedar are also impacted by the climate change, so I just can't see still harvesting... the way we used to do.
Psychological adaptations occurred within all knowledge groupings, but were reported more frequently by those who knew about the link to climate change. The quality of these responses varied in intensity between low versus high knowledge groupings, as did the intended outcomes (i.e., self versus others). Whereas connecting served to help users not aware of the climate change link grapple with the unknown causes, connecting for users in group three enabled them to cope with their knowledge of the global nature of climate change and its impacts on the local environment.

As one user explained:

Yellow-cedar is one of those [species] that seems to be more susceptible to small changes, and the fact that yellow-cedar can stand dead for so long without falling is a looking-glass to the original sin of particular matter.

Users in group three commonly discussed psychological adaptations with intended outcomes that affected both themselves and others (e.g., coping by focusing on the need to repair human-environment relationships, or actively moving through a grief process in community). These psychological adaptations were more salient and pressing for those with more knowledge.

Another said:

It's of a global nature, and that's a really hard thing to stop. So maybe the question is this: what nourishes, facilitates, and what severs connection? What is each of our roles in this? The more connected we can become, the happier we are going to be amidst the changes occurring. We resonate.

Seven out of the eight managers who knew about the link to climate change reported expanding their perspective of forests spatially and temporally, whereas the other psychological adaptations (Table 2) were largely exclusive to forest users.

One manager expressed:

\section{If you think long-term enough, it'll be fine.}

Another stated:

It's just understanding ecology in that [yellow-cedar] will probably move north and upward.

Managers who knew about the climate change link often perceived the ecological changes occurring as part of a natural process or as accelerations of dynamics already occurring. Users who expanded their perspectives of forests spatially and temporally related the intended outcomes of this adaptive response to themselves as a means to cope with their understanding of the changes occurring, whereas managers focused on the outcomes for the tree species across its range.

One forest user, a scientist, explained:

I'm getting better at visualizing deep time both directions. It makes me realize the present moment of human depredation is definitely going to be fleeting.

Adaptive responses to the climate-induced dieback were often intertwined with responses to other environmental changes affecting the species, such as logging practices. Those 
Fig. 2. Examples of overlapping content in responses. Quotations are in regular type. The coded use values, attachment, and attitudes are bracketed in italics above the occurrence.

How would you describe your relationship to the coastal forests in southeast?

[emotional attachment] [forest scale]

"We could not be who we are, Tlingit people... if we did not have our forest. It gives us our identity. We

[heritage] [intangible value]

are who we are because of the trees. The trees remember our ancestors. The trees remember all the

[customary \& traditional use] [direct use value]

grandmas that I didn't know, and they tell me about them... The trees and I, we communicate. It's just

you have to learn how to listen."

Do you think of yourself and these yellow-cedar forests as connected in any ways?

[emotional attachment] [species scale]
"I put myself in the presence of cedar on a regular basis. You almost have to. They're such different
[existence] [intangible value] [recreational use] [direct use value]
personalities... you have to go spend time with them on their own. I desperately want to have
[direct use value] [wood products] [aesthetic]
[functional attachment] [species scale]
[existence]
out at arm's length. I'm wanting them to be close to me and be a part of my life on a daily basis."

\begin{abstract}
[functional attachment] [species scale] [economic]
[concern] [local \& regional scale]

"I built my business around red and yellow-cedar, frankly... I'm concerned about all the dead cedar...

[direct use value] [wood products]

I really hope they are utilized because we do need yellow-cedar as far as a tree... We should harvest

them and start using them."
\end{abstract}

knowledgeable of the dieback's link to climate change often considered climate change as an additional stressor to a slowgrowing species with a history of harvesting. The dieback exacerbated existing challenges from historical logging to maintain a viable population for future harvest or to cope with losses due to harvests.

\section{Mediating factors influencing adaptation}

As interviewees described their relationship to yellow-cedar trees, coastal forests, and individual forest-related experiences, many responses exhibited the bundling (Klain et al. 2014, Gould et al. 2015) of multiple use values, attitudes, and attachment (Fig. 2). The patterns observed across the dataset provided further insight into the ways in which these affective and evaluative factors mediate between knowledge and adaptation (Fig. 3).

\section{Attitudes}

We identified a set of attitudes about the species' dieback and the changes occurring (Table 3), and observed specific attitudes characteristic of users aware of the dieback and its causal link to climate change (groups two and three). These attitudes included concern that emphasized the global nature of climate change, and fear, hopelessness, lacking self-efficacy, and a sense that these environmental changes are indicative of future impacts. Users in these groups commonly expressed negative attitudes, and those more knowledgeable emphasized these negative attitudes more extensively in discussion.
Fig. 3. Cognitive, affective, and evaluative factors that interact to affect behavioral and psychological adaptations at the individual actor level.

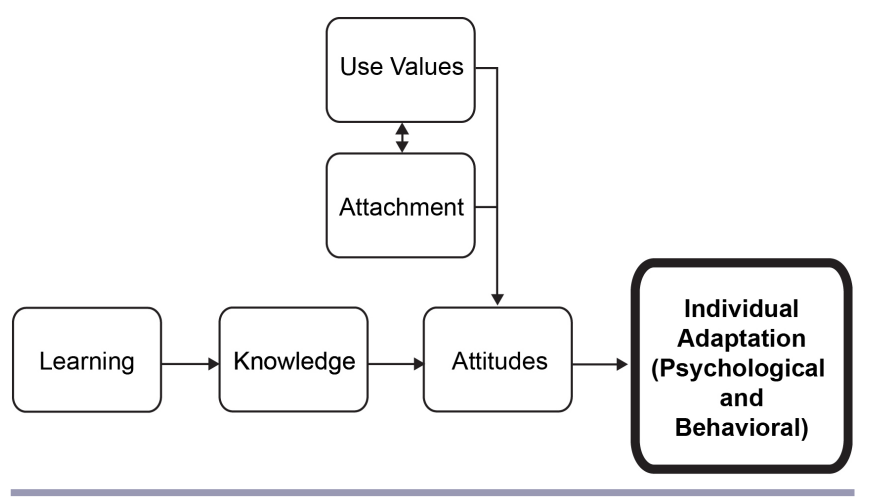

One interviewee stated:

These huge changes just feel so intractable to try and push against.

Knowledgeable users in group three expressed concerns across multiple scales, discussing local losses of the species or additional climate change impacts at multiple scales (e.g., stream temperatures, fisheries, sea-level rise, and ocean acidification). 
Table 3. Attitudes expressed by forest users and managers.

\begin{tabular}{|c|c|c|}
\hline Attitude & Scale / Type & Description \\
\hline Apathetic & & Little or no expression of interest, enthusiasm, or concern \\
\hline \multirow[t]{4}{*}{ Concerned } & & Expression of affect, such as worry \\
\hline & Locally concerned & Focused concern at local community scale or "backyard" \\
\hline & Regionally concerned & Focused concern at regional scale (e.g., forest health across the southeast archipelago) \\
\hline & Globally concerned & Focused concern at global scale (e.g., dieback is an indicator of other larger problems) \\
\hline \multirow[t]{7}{*}{ Negative } & & Characterized by negativism \\
\hline & Aesthetically focused & Focused on physical appearance \\
\hline & Averse & Disinterest \\
\hline & Fearful & Distress aroused by future impending impacts \\
\hline & Hopeless & Doubtful of possibilities to resolve; expression of despair, without hope \\
\hline & Lacking self-efficacy & Expression of personal inability to do anything \\
\hline & Pessimistic & Tending to identify the worst aspects; focused on losses (e.g., economic, others) \\
\hline Questioning & & Interested or eager to learn more \\
\hline Optimistic & & Hopeful or positive about future outcomes \\
\hline Pragmatic & & Realistic and sensible approach based upon practical rather than theoretical \\
\hline Utilitarian & & Focused on usefulness, practical, or material exploitation \\
\hline
\end{tabular}

One user explained:

I worry about the yellow-cedar because it's... one of those indicator species... like the canary in the coal mine of saying: we're starting to lose it. And we might be able to point back 20, 30 years from now and say: if we had paid more attention to the yellow-cedar, we would have seen the fraying of this ecosystem.

By contrast, forest managers in groups two and three commonly expressed more pragmatic, utilitarian attitudes.

Psychological adaptations enabled interviewees to process specific emotions spurred by their knowledge of climate change as the causal mechanism of the dieback. Broadening one's spatial and temporal perspective of forests, for example, enabled users to shift their negative attitudes about the short-term, localized losses of this tree toward more optimistic perspectives on longterm changes.

One user in group three explained:

To grieve for the loss of a cedar is [a] piece of the meditation, and then to act from that meditation is yet another piece.

We did not find that these negative emotions hindered behavioral responses, because participants expressing attitudes of fear, hopelessness, and even lack of self-efficacy commonly reported behavioral adaptations. Knowledgeable interviewees, who expressed global concern, commonly reported behavioral changes with outcomes intended to make a difference at that scale, such as educating others about climate change impacts.

One user shared:

Well, it's pretty sad... It was my favorite conifer around here so it's a loss of that particular tree [that feels] personal. I'm not sure how to stop [climate] change other than to stop driving my car and convincing everyone else in the whole world to do the same thing.

This user, like others with his knowledge and negative attitude, still adopted a suite of behavioral responses, such as substitution, opportunistic use, and preferential use, along with others, like restraint by reducing home energy use. Thus, having negative attitudes did not preclude a sense of optimism; many forest users and managers expressed both.

As one manager explained:

It is the plight of the modern-day environmentalist where one oscillates between utter despair and steady optimism.

Those who felt hopeless also wanted to know what they could do at a local level to help the yellow-cedar population, reported a lack of self-efficacy, and questioned what would inspire collective action to address climate change. Those individuals still adopted multiple forms of behavioral and psychological adaptations.

Use values and attachment

We found clear patterns of use values and place attachment influencing specific attitudes: local and regional concern, as well as pessimism about losses. These affective and evaluative factors helped explain the variation we observed in attitudes and mediate between knowledge and adaptation (Fig 3).

Individuals who reported direct use values of yellow-cedar trees, such as hunting, harvesting, or educational use (Table 4), were able to make substitutions, adapt to new opportunities created in the affected forests, or adopt other forms of behavioral adaptation. By contrast, we found that interviewees associated many intangible values with live forests; these values were different from those attributed to affected forests (Table 5). Benefits not attributed to affected forests included, for example, specific spiritual values, feelings of enhanced well-being, and cultural heritage. Users who derived these intangible values experienced irreplaceable losses.

As one Native Alaskan interviewee expressed:

We are who we are because of the trees... [They] remember all my grandmothers that I didn't know, and they tell me about them.

Another stated:

It's always uplifting to walk into the forest among the cedars. I think the cedars and my ancestors and myself have a kinship that goes back 10,000 years. 
Table 4. Reported direct-use values for live yellow-cedar trees and unaffected forests, as distinguished by study participants from dead yellow-cedar trees and affected forests. Use values listed are those reported that were discussed as past and present use values, not hypothetical future-use values.

\begin{tabular}{|c|c|c|}
\hline Direct-use value & Use of live yellow-cedar; unaffected forests & Use of dead yellow-cedar; affected forests \\
\hline Art & $\begin{array}{l}\text { Painting on wood; non-Native wood carving } \\
\text { (figurines, coat hooks, cedar plaques) }\end{array}$ & Non-Native carving (arrows, bowls) \\
\hline $\begin{array}{l}\text { Customary and } \\
\text { traditional }\end{array}$ & $\begin{array}{l}\text { Bark use (weaving blankets, clothing, hats; adding to tobacco or snuff } \\
\text { for healing properties; fishing line; trading); using trees to construct } \\
\text { houses or canoes; wood carving (totem poles, panels, masks, bentwood } \\
\text { boxes, bowls, ladles, fishing hooks, paddles); collecting bark in forests; } \\
\text { visiting culturally modified trees; hunting and gathering (e.g., berries, } \\
\text { plant leaves) in unaffected forests }\end{array}$ & N/A \\
\hline Educational & $\begin{array}{l}\text { Using trees to teach Native carving and weaving, as tools in } \\
\text { community-building projects and teen intervention through carving or } \\
\text { visiting forests, and, along with unaffected forests, to teach others } \\
\text { about ecological values of old growth forests and local botany; } \\
\text { understanding the species; counting rings }\end{array}$ & $\begin{array}{l}\text { Using dead trees and affected forests to educate others } \\
\text { about climate change; using trees in community-building } \\
\text { projects }\end{array}$ \\
\hline Environmental & $\begin{array}{l}\text { Using yellow-cedar wood instead of chemically treated wood products } \\
\text { (value of reducing local pollution through leaching) }\end{array}$ & Using dead trees as an alternative to harvesting live trees \\
\hline Economic & $\begin{array}{l}\text { Exporting trees internationally; valuing trees in local timber industry } \\
\text { and small-scale mill operations; providing employment (tourism, } \\
\text { commercial logging and forest products, research); value-added timber } \\
\text { processing; valuing yellow-cedar trees and healthy forests in tourism } \\
\text { industry }\end{array}$ & $\begin{array}{l}\text { Valuing trees in local timber industry and small-scale mill } \\
\text { operations; providing employment (commercial logging } \\
\text { and forest products, research); value-added timber } \\
\text { processing; small timber sales through salvage; added } \\
\text { value because of public appeal of using dead wood, as } \\
\text { opposed to live }\end{array}$ \\
\hline $\begin{array}{l}\text { Forest products } \\
\text { and personal }\end{array}$ & $\begin{array}{l}\text { Using trees for structural supports (anchors for power transmission } \\
\text { tower, beams, pilings, trusses, framing); interior woodwork (trim, } \\
\text { molding, paneling, countertops, sills, handrails); furniture (Japanese } \\
\text { screens); construction and exterior use (local homes, Japanese temples, } \\
\text { recreational facilities and public structures; siding; picnic tables; } \\
\text { benches; decks; piers; bridges, saunas); boat construction; musical } \\
\text { instruments; trail construction; wood-pellet heating; firewood; bark use } \\
\text { (emergency fire starter); use of forests for timber surveys }\end{array}$ & $\begin{array}{l}\text { Using trees for structural supports (pilings); interior } \\
\text { woodwork (trim, paneling, cabinets, handrails, furniture); } \\
\text { construction and exterior use (local homes, poles for } \\
\text { power lines); boat construction; trail construction; wood } \\
\text { pellet heating; firewood }\end{array}$ \\
\hline Ecological & $\begin{array}{l}\text { Seedling forage for deer and moose; supporting biodiversity; use of } \\
\text { bark for deer and bear beds; consumption of cones by squirrels; niche } \\
\text { habitat; fostering healthy watersheds and supporting fisheries; carbon } \\
\text { sequestration; moisture retention }\end{array}$ & $\begin{array}{l}\text { Shrub forage for deer and other wildlife; providing } \\
\text { nutrients back to forest through decay process; niche } \\
\text { habitat (home for cavity nesters, insects, or wildlife); value } \\
\text { of nurse logs to foster regeneration }\end{array}$ \\
\hline Landscaping & Planting seedlings or transplanting live trees & N/A \\
\hline $\begin{array}{l}\text { Physical } \\
\text { properties }\end{array}$ & $\begin{array}{l}\text { Providing refuge under tree canopy from mosquitoes; rot resistance; } \\
\text { valuing functionality and unique qualities of tight-grained wood for } \\
\text { carving and building; licking sap; chewing bark for taste, tannins, or } \\
\text { healing properties }\end{array}$ & $\begin{array}{l}\text { Valuing checked aesthetic, spalting, or reduced dry time } \\
\text { for wood products use; intensified qualities for firewood } \\
\text { use (rapid, hot burning) }\end{array}$ \\
\hline Recreation & $\begin{array}{l}\text { Intentionally visiting forests with live yellow-cedar; hiking; observing } \\
\text { wildlife }\end{array}$ & Hiking \\
\hline $\begin{array}{l}\text { Religious } \\
\text { ceremony }\end{array}$ & $\begin{array}{l}\text { Using trees for bows in Russian Orthodox Church; using foliage for } \\
\text { holiday wreaths or ceremonial purposes }\end{array}$ & N/A \\
\hline Research & $\begin{array}{l}\text { Using trees for research (species traits, ecological processes; } \\
\text { paleoecology; dendrochronology); studying favorable site conditions }\end{array}$ & $\begin{array}{l}\text { Using trees for research (ecological processes; } \\
\text { paleoecology; dendrochronology; climate change } \\
\text { impacts); studying favorable site conditions }\end{array}$ \\
\hline $\begin{array}{l}\text { Sport hunting } \\
\text { and gathering }\end{array}$ & Hunting and gathering (e.g., berries) in unaffected forests & Hunting \\
\hline
\end{tabular}

The loss of aesthetic and spiritual values helped explain some differences between direct uses of affected and unaffected forests because interviewees who perceived these values as impacted tended to physically avoid the affected forests. Responses included, for example, "There's something disheartening about it...like going to a graveyard," and "I have not [walked in affected forests], and that's not by accident...They make me uncomfortable." Managers tended to focus on direct use values and the intangible values held by others, such as cultural values or Native heritage; however, few shared personal intangible values for live yellow-cedar trees or unaffected forests, such as feeling recharged or inspired.
Most described a sense of place and place attachment to southeast Alaska, but those who derived direct uses and intangible values from the trees expressed functional and emotional attachments at a finer scale. This species-level attachment resulted in escalated attitudes of concern and pessimism, irrespective of knowledge grouping, as interviewees acknowledged potential economic implications or expressed remorse for loss of intangible benefits.

Managers seldom distinguished their personal attachment to yellow-cedar as distinct from other species, but rather focused on their relationship at the forest level. E.g.: 
Table 5. Reported intangible values for live yellow-cedar trees and unaffected forests, as distinguished by study participants from dead yellow-cedar trees and affected forests. Values listed are those that were discussed as past and present use values (arising indirectly or through nonuse), not hypothetical future use values.

\begin{tabular}{|c|c|c|}
\hline Intangible value & Values of live yellow-cedar; unaffected forests & Values of dead yellow-cedar; affected forests \\
\hline Age & Appreciating antiquity & N/A \\
\hline Aesthetic & $\begin{array}{l}\text { Appreciating scent; soft bark; soft needles; beautiful bark color; sound } \\
\text { of wind in branches }\end{array}$ & Appreciating scent \\
\hline $\begin{array}{l}\text { Other } \\
\text { people's }\end{array}$ & $\begin{array}{l}\text { Appreciating other people's cultural use values (Alaska Native or } \\
\text { Japanese) }\end{array}$ & N/A \\
\hline $\begin{array}{l}\text { Nature } \\
\text { connection }\end{array}$ & $\begin{array}{l}\text { Feeling attached; fostering mutual respect between humans and nature; } \\
\text { feeling intrigued by a mysterious species to learn more about local and } \\
\text { regional ecology; perceiving trees as vessels of history (bearing witness to } \\
\text { a long period of social and ecological history) }\end{array}$ & $\begin{array}{l}\text { Fostering mutual respect between humans and nature; } \\
\text { feeling intrigued by a mysterious species to learn more } \\
\text { about local and regional ecology and causes of dieback }\end{array}$ \\
\hline $\begin{array}{l}\text { Human well- } \\
\text { being }\end{array}$ & $\begin{array}{l}\text { Feelings of happiness, gratitude, love, calmness, improved human well- } \\
\text { being }\end{array}$ & Learning from experience of sadness or grief \\
\hline Heritage & $\begin{array}{l}\text { Remembering ancestors; communicating with ancestors; perceiving trees } \\
\text { as an avenue for retaining cultural identity; appreciating the "memory" } \\
\text { of trees (markings of ancestors retained in bark structure) }\end{array}$ & N/A \\
\hline Spiritual & $\begin{array}{l}\text { Feeling reverence; feeling inspired through meditation; perceiving the } \\
\text { species as gift from God }\end{array}$ & Feeling reverence for a spiritual life still within \\
\hline Existence & $\begin{array}{l}\text { Appreciating unique species and relatively limited abundance; value of } \\
\text { one species as part of the whole; appreciating healthy forests in a context } \\
\text { of global scarcity; biodiversity }\end{array}$ & $\begin{array}{l}\text { Valuing the standing dead as an indicator of change; } \\
\text { valuing tree mortality as part of a natural process }\end{array}$ \\
\hline Symbolic & Recognizing as iconic of wilderness & $\begin{array}{l}\text { Recognizing scale of climate change impacts occurring, } \\
\text { even in protected areas }\end{array}$ \\
\hline
\end{tabular}

I love woods and I love trees. I can see how particular trees would be important; put me in a ponderosa pine forest, I'm just as happy.

However, the few managers who exhibited psychological adaptations, other than spatial and temporal expansion, expressed a personal attachment to the species and associated the live forests with intangible values. Managers and some users who had relatively limited direct uses of yellow-cedar trees or personal experience in these forests did not seem to develop a sense of emotional attachment to yellow-cedar trees. Instead, the use values applied by other people or management objectives shaped functional attachment. Pessimism about losses and concern across multiple scales were most salient for interviewees with a high level of knowledge developed through a combination of place-based and social learning, functional and/or emotional attachments to the species itself, and use values, often intangible ones, that could not be substituted between the affected and unaffected forests.

\section{DISCUSSION}

\section{Individual-level adaptation}

Our study provides empirical evidence for the cognitive, affective, and evaluative factors that interact to influence individual adaptation, and it illuminates distinct psychological and behavioral responses that may emerge in an ecosystem experiencing widespread, climate-induced impacts, such as tree mortality. Quantitative results (i.e., PERMANOVA) indicate that knowing specific environmental changes are induced by climate change, as opposed to simply being aware that those environmental changes are occurring, is associated with different behavioral and psychological adaptations. These findings were further supported by our qualitative analyses. We found a diversity of response actions that include, for example, opportunistically using or exploiting new opportunities in the dynamic ecosystem, physically avoiding places where impacts occur, and using impacts in the local environment to educate others about climate change. We also discovered a suite of other psychological adaptations, such as focusing on deepening connections within communities in the region and expanding one's view of the impacted system temporally and spatially, to cope with the changing ecological dynamics. Our data indicate that knowledge alone does not motivate differing responses; attitudes mediate knowledge and adaptation. Specific attitudes, such as concern at a global scale, were characteristic of users who were more knowledgeable about the dieback's causal link to climate change and helped explain variation in adaptive responses. Attachment to the species was deeply intertwined with the use values that various respondents described deriving from the species. Together, these factors helped shape attitudes toward the occurring impacts.

We found that knowing that the diminishment of a species was attributed to climate change could precipitate feelings of concern across multiple scales, pessimism about losses, hopelessness, and fear, particularly for resource users. Doherty and Clayton (2011) differentiated between classes of psychological impacts of climate change: direct, e.g., acute or traumatic effects of extreme weather or a changed environment; indirect, e.g., threats to emotional wellbeing based on observation of impacts, and concern or uncertainty about future risks; and psychosocial, e.g., chronic social and community effects of heat, drought, or climate-related conflicts. Many, but not all, knowledgeable participants adopted coping strategies for their negative feelings. Starting with concrete concepts and experiences in place to encourage reflection, thought, and action, Wibeck (2014) argued that focusing on locally relevant climate change impacts in communications may 
help encourage individuals to act by connecting to people's emotions and concerns (O'Neill and Nicholson-Cole 2009). Because the more knowledgeable participants in our study tended to learn about the dieback through a combination of indirect learning experiences coupled with direct, place-based learning, our findings suggest that a greater depth of knowledge about climate-related impacts in the local environment may develop through such an integrated avenue. Although some Native Alaskans did not report actively, nor perhaps even consciously, learning about the climate-related causal mechanism, they drew from historical observations and cultural stories of the changing environment to hypothesize a link between tree death, root injury, and climate change. Riedlinger and Berkes (2001) identified areas, such as local-scale expertise, sources of climate history, hypothesis formulation, and understanding impacts and adaptation in northern communities, in which traditional knowledge may complement western scientific knowledge. The attitudes that we found to be associated with knowledge of the causal mechanisms indicate that deepening knowledge may also spark a suite of negative emotions. Fritze et al. (2008) suggested that the longer term impact of climate change on mental health may derive from people's emerging awareness of climate change as a global threat. Our findings on the attitudes influenced by climate-related knowledge in this particular ecosystem add empirical evidence to these claims.

Feelings of hopelessness and inefficacy related to climate change have been linked with a tendency to ignore the problem or to rationalize inaction (Norgaard 2011). By contrast, we found that experiencing these negative emotions did not inhibit action. Rather, individuals who reported similar behaviors acted within their capacity to adopt activities with intended outcomes that extended beyond the local environment. These activities included, for example, raising climate change awareness by educating visitors to the region through the dieback or choosing more energy-efficient behaviors. The adaptations attributed to more knowledgeable participants suggest that adaptation at the individual level may be a mixture of self-interest and prosocial motives (e.g., concern for other people, the next generation, other species, or whole ecosystems), a dynamic similar to those observed in proenvironmental behavior (Bamberg and Möser 2007). With a greater depth of knowledge, individuals can conceptualize the problem at a global level (Uzzell 2000) and extrapolate their direct local experience to more distant places. We found that psychological adaptations enabled some interviewees to process these negative emotions, even though not all of those expressing feelings of hopelessness, inefficacy, and fear expressed coping strategies. The Australian Psychological Society, for example, offers ways of responding to climate change and other globalscale environmentally related issues, some of which are similar to the adaptations we observed, i.e., talking with others about problems and modeling through individual action changes one would like to see at a global scale (APS 2007). As resource users become aware of the climate-induced causes of impacts occurring in their own environment in other systems impacted by climate change, they may benefit from programs that facilitate psychological adaptation to the emerging ecosystem.

Our study indicates that fine-scale ecological dynamics, such as a species dieback in forests, may disproportionately affect people who attribute nonsubstitutable intangible values or attachment to specific ecosystem components. Because long-living trees span several human generations, the trees constitute a living link between and among people (Blicharska and Mikusińksi 2013). Awareness of old trees as part of human identity and cultural heritage is critical when considering worldwide decline (Blicharska and Mikusińksi 2014). Our study provides evidence that attachment not only extends beyond place to individual species, but also that fine-scale species attachment influences attitudes about the occurrence of impacts. Interviewees with emotional attachment to the dieback-affected species, who associated unaffected forests with intangible benefits, such as cultural history, expressed deeper concern. Broader ecosystem changes, such as coastal inundation, can displace people from places they value (Adger et al. 2012) and have an impact on cultures when there are few substitutions for lost significant sites (Kirsch 2001, Crate 2008, Ford et al. 2010, Garrett 2010). In contrast, many direct uses we found were substitutable between forests affected and unaffected by the decline, and between live and dead trees. Forest users who could benefit from these new uses felt less concerned about the losses and were able to take advantage of the emerging conditions.

\section{Implications for management}

Adaptive behaviors exhibited by managers, such as preferentially selecting less healthy trees for harvest or experimenting with planting, indicate that individuals who are knowledgeable about ecosystem dynamics may be better able to integrate that information into existing management practices before policies are adapted. Management practices can influence the timing and direction of changing forest dynamics at specific locations (Spittlehouse 2005). Although 11 managers is a small number of respondents, the individuals in our sample oversee large tracts of land. At the time of these interviews, nine USDA employees managed designated wilderness areas throughout the region and nine individuals held positions as professional foresters. Although adaptive practices implemented were not generalizable to the management population, the actions undertaken by relatively few people can have notable future implications. Our findings suggest that obtaining a depth of knowledge about the interactions between climate change and site conditions favorable to the species across its range may be central to motivating managers' adaptive practices; understanding the linkages helped managers identify research gaps to implement experimental plantings, for example, or promote individual trees where they may be more likely to survive. Future research might include testing the link between depth of knowledge and decision making on adaptive management practices by using a larger sample frame and a survey-based methodology in another system experiencing climate-related impacts. There may also be feedbacks that make determining the directionality of causal relationships difficult; undertaking adaptive practices could also influence knowledge, attitudes, and use values that an individual derives from the system that has been impacted.

\section{Limitations}

In this study, we did not select interviewees to be representative of the regional population, but rather to provide insight into individual adaptation by including people with diverse relationships to forests in southeast Alaska. Some of the adaptations we observed, such as educating others about climatechange impacts, could be interpreted as engagement, i.e., a state 
of connection through codependent spheres of cognition, affect, and behavior (Lorenzoni et al. 2007), or mitigation, such as reducing personal energy consumption. Our analyses aimed to identify individual adjustments, which can include engagement or behavioral changes that move toward mitigation.

The interviewees' perception of the researcher as an outsider or an expert may have affected the perspectives they shared. As such, interviewees may have been less likely to share psychologically or emotionally charged responses or express attitudes of concern, even though researchers were careful to consider reflexivity in interactions and interpretation (Bourdieu and Wacquant 1992, Alvesson and Sköldberg 2009). Despite our attempt to minimize framing effects, the ways in which questions were asked, and the context in which forests were discussed, may have influenced individuals' responses (Satterfield 2001, Lakoff 2010, Gould et al. 2015). Finally, attributing adaptations to climate change is not simple because these adaptations occur in the context of other events (Adger et al. 2005). Attitudes about the species dieback, such as concern, may have been exacerbated by existing concerns about the impact of historic logging practices on the species. We did not attempt to isolate adaptive responses to the species dieback from the context of past and present land use; rather, we aimed to understand how knowing about the dieback's causal link to climate change may influence different responses. We recognize that not all responses to climate change and its effects may be adaptations and that other scholars might categorize these responses differently, e.g., in accordance with standard IPCC practices (Parry et al. 2007), such as mitigation and adaptation.

\section{CONCLUSION}

Moving beyond the focus of adaptation on adjustments in natural or human systems, our study provides empirical evidence that adaptation, at a finer scale, includes a breadth of psychological coping processes and behavioral changes at the individual level that aim to minimize losses or exploit new opportunities. Cognitive, affective, and evaluative factors known to motivate behavioral change also apply to an ecosystem impacted by climate change and interact to affect the ways in which individuals respond to the changing environment. Knowing that local environmental changes that are occurring are associated with climate change may lead individuals to adapt in different ways. We found this knowledge was commonly associated with psychological adaptations to process negative emotions and behavioral changes that recognize the global nature of climate change. This was particularly true for knowledgeable forest users, who expressed salient psychological coping processes, whereas forest managers focused on the forest resource and integration of their knowledge of the impacts occurring across multiple scales (i.e., site level to range wide) into adaptive practices.

Influenced by cognitive, affective, and evaluative factors at the individual actor level, managers may implement adaptive practices in advance of policies. As knowledge of climate-change impacts in local environments increases, our study suggests that adaptive management may occur from the bottom up. Our findings also highlight the importance of interventions that facilitate coping strategies as community members develop new relationships with the emerging ecosystem.
Responses to this article can be read online at: http://www.ecologyandsociety.org/issues/responses. $\mathrm{php} / 8464$

\section{Acknowledgments:}

Funding for this study was provided by Stanford University's School of Earth, Energy, and Environmental Sciences, the USDA Forest Service, and The Wilderness Society Gloria Barron Fellowship. L. E.O. was supported by a National Science Foundation Graduate Research Fellowship and the Emmett Interdisciplinary Program in Environment and Resources at Stanford University. We thank the study interviewees for sharing their perspectives and for their generosity in time, trust, and hospitality. The USDA Forest Service Forest Health, Sitka District Forest Service, Hoonah District Forest Service, and many community members provided housing support for the lead author during data collection. L. Petershoare and B. Lindekugel provided assistance identifying Native community members for study participation and reviewing participant groupings with sensitivity to legal perspectives on subsistence uses. We thank J. Felis for GIS support (Fig. 1), as well as C. Woolsey, R. Malczynski, and N. Wyman at Stanford University for coding assistance. Comments from F. Moore, A. Cravens, and A. Becker improved this manuscript, and W. Hoover provided copyedits.

\section{LITERATURE CITED}

Adger, W. N. 2003. Social capital, collective action, and adaptation to climate change. Economic Geography 79 (4):387-404. http://dx.doi.org/10.1111/j.1944-8287.2003.tb00220. $\underline{x}$

Adger, W. N., N. W. Arnell, and E. L. Tompkins. 2005. Successful adaptation to climate change across scales. Global Environmental Change 15(2):77-86. http://dx.doi.org/10.1016/j.gloenvcha.2004.12.005

Adger, W. N., J. Barnett, K. Brown, N. Marshall, and K. O’Brien. 2012. Cultural dimensions of climate change impacts and adaptation. Nature Climate Change 3(2):112-117. http://dx.doi. org/10.1038/nclimate1666

Adger, W. N., S. Dessai, M. Goulden, M. Hulme, I. Lorenzoni, D. R. Nelson, L. O. Naess, J. Wolf, and A. Wreford. 2009. Are there social limits to adaptation to climate change? Climatic Change 93(3):335-354. http://dx.doi.org/10.1007/s10584-008-9520$\underline{Z}$

Albert, D. M., and J. W. Schoen. 2013. Use of historical logging patterns to identify disproportionately logged ecosystems within temperate rainforests of southeastern Alaska. Conservation Biology 27(4):774-784. http://dx.doi.org/10.1111/cobi.12109

Allen, C. D., and D. D. Breshears. 2007. Climate-induced forest dieback as an emergent global phenomenon. Eos Transactions American Geophysical Union 88(47):54. http://dx.doi. org/10.1029/2007eo470008

Allen, C. D., A. K. Macalady, H. Chenchouni, D. Bachelet, N. McDowell, M. Vennetier, T. Kitzberger, A. Rigling, D. D. Breshears, E. H. Hogg, P. Gonzalez, R. Fensham, Z. Zhang, J. Castro, N. Demidova, J.-H. Lim, G. Allard, S. W. Running, A. 
Semerci, and N. Cobb. 2010. A global overview of drought and heat-induced tree mortality reveals emerging climate change risks for forests. Forest Ecology and Management 259(4):660-684. http://dx.doi.org/10.1016/j.foreco.2009.09.001

Alvesson, M., and K. Sköldberg. 2009. Reflexive methodology: new vistas for qualitative research. Sage, Thousand Oaks, California, USA.

Ardoin, N. M. 2006. Toward an interdisciplinary understanding of place: lessons for environmental education. Canadian Journal of Environmental Education 11(1):112-126. [online] URL: https:// people.stanford.edu/nmardoin/sites/default/files/documents/Ardoin. pdf

Australian Psychological Society (APS). 2007. Tip sheet: climate change - what you can do. Australian Psychological Society, Melbourne, Australia. [online] URL: https://www.psychology. org.au/publications/tip sheets/climate/

Ballard, H. L., and J. M. Belsky. 2010. Participatory action research and environmental learning: implications for resilient forests and communities. Environmental Education Research 16 (5-6):611-627. http://dx.doi.org/10.1080/13504622.2010.505440

Bamberg, S., and G. Möser. 2007. Twenty years after Hines, Hungerford, and Tomera: a new meta-analysis of psycho-social determinants of pro-environmental behaviour. Journal of Environmental Psychology 27(1): 14-25. http://dx.doi.org/10.1016/ j.jenvp.2006.12.002

Bandura, A. 1977a. Self-efficacy: toward a unifying theory of behavioral change. Psychological Review 84(2):191-215. http://dx. doi.org/10.1037/0033-295X.84.2.191

Bandura, A. 1977b. Social learning theory. Prentice-Hall, Englewood Cliffs, New Jersey, USA.

Beier, C. M., S. E. Sink, P. E. Hennon, D. V. D’Amore, and G. P. Juday. 2008. Twentieth-century warming and the dendroclimatology of declining yellow-cedar forests in southeastern Alaska. Canadian Journal of Forest Research 38:1319-1334. http://dx.doi. org/10.1139/X07-240

Benson, M. H., and R. K. Craig. 2014. The end of sustainability. Society and Natural Resources 27(7):777-782. http://dx.doi. org/10.1080/08941920.2014.901467

Birch, S. K., and K. E. Schwaab. 1983. The effects of water conservation instruction on seventh-grade students. Journal of Environmental Education 14(4):26-31. http://dx.doi. org/10.1080/00958964.1983.9943478

Blicharska, M., and G. Mikusińksi. 2013. Old trees: cultural value. Science 339:904. http://dx.doi.org/10.1126/science.339.6122.904$\underline{\mathrm{b}}$

Blicharska, M., and G. Mikusińksi. 2014. Incorporating social and cultural significance of large old trees in conservation policy. Conservation Biology 28(6):1558-1567. http://dx.doi.org/10.1111/ cobi. 12341

Bourdieu, P., and L. J. Wacquant. 1992. An invitation to reflexive sociology. University of Chicago Press, Chicago, Illinois, USA.

Chapin, F. S., III, S. F. Trainor, O. Huntington, A. L. Lovecraft, E. Zavaleta, D. C. Natcher, A. D. McGuire, J. L. Nelson, L. Ray,
M. Calef, N. Fresco, H. Huntington, T. S. Rupp, L. DeWilde, and R. L. Naylor. 2008. Increasing wildfire in Alaska's boreal forest: pathways to potential solutions of a wicked problem. BioScience 58:531-540. http://dx.doi.org/10.1641/B580609

Crate, S. A. 2008. Gone the bull of winter? Grappling with the cultural implications of and anthropology's role(s) in global climate change. Current Anthropology 49:569-595. http://dx.doi. org/10.1086/529543

Creswell, J. W. 2012. Qualitative inquiry and research design: choosing among five approaches. Sage, Thousand Oaks, California, USA.

D'Amore, D. V., and P. E. Hennon. 2006. Evaluation of soil saturation, soil chemistry, and early spring soil and air temperatures as risk factors in yellow-cedar decline. Global Change Biology 12(3):524-545. http://dx.doi.org/10.1111/ j.1365-2486.2006.01101.x

DellaSala, D. A., P. Alaback, T. Spribille, H. von Wehrden, and R. S. Nauman. 2011. Just what are temperate and boreal rainforests? Pages 1-41 in D. A. DellaSala, editor. Temperate and boreal rainforests of the world: ecology and conservation. Island, Washington, D.C., USA.

Devine-Wright, P. 2009. Rethinking NIMBYism: the role of place attachment and place identity in explaining place protective action. Journal of Community and Applied Social Psychology 19:426-441. http://dx.doi.org/10.1002/casp.1004

Doherty, T. J., and S. Clayton. 2011. The psychological impacts of global climate change. American Psychologist 66(4):265-276. http://dx.doi.org/10.1037/a0023141

Finger, M. 1994. From knowledge to action? Exploring the relationships between environmental experiences, learning, and behavior. Journal of Social Issues 50(3):141-160. http://dx.doi. org/10.1111/j.1540-4560.1994.tb02424.x

Flint, C. G. 2006. Community perspectives on spruce beetle impacts on the Kenai Peninsula, Alaska. Forest Ecology and Management 227:207-218. http://dx.doi.org/10.1016/j.foreco.2006.02.036

Folke, C. 2006. Resilience: the emergence of a perspective for social-ecological systems analyses. Global Environmental Change 16(3):253-267. http://dx.doi.org/10.1016/j.gloenvcha.2006.04.002

Fonseca, B. A., and M. T. H. Chi. 2011. Instruction based on selfexplanation. Pages 296-321 in R. E. Mayer and P. A. Alexander, editors. The handbook of research on learning and instruction. Routledge, New York, New York, USA. http://dx.doi. org/10.4324/9780203839089.ch15

Ford, J. D., T. Pearce, F. Duerden, C. Furgal, and B. Smit. 2010. Climate change policy responses for Canada's Inuit population: the importance of and opportunities for adaptation. Global Environmental Change 20(1):177-191. http://dx.doi.org/10.1016/ j.gloenvcha.2009.10.008

Fritze, J. G., G. A. Blashi, S. Burke, and J. Wiseman. 2008. Hope, despair and transformation: climate change and the promotion of mental health and wellbeing. International Journal of Mental Health Systems 2(1):13. http://dx. doi.org/10.1186/1752-4458-2-13

Garrett, B. L. 2010. Drowned memories: the submerged places of the WinnememWintu. Archaeologies 6:346-371. http://dx.doi. org/10.1007/s11759-009-9109-9 
Gee, K., and B. Burkhard. 2010. Cultural ecosystem services in the context of offshore wind farming: a case study from the west coast of Schleswig-Holstein. Ecological Complexity 7(3):349-358. http://dx.doi.org/10.1016/j.ecocom.2010.02.008

Glaser, B. G. 1992. Basics of grounded theory analysis: emergence vs. forcing. Sociology, Mill Valley, California, USA.

Gonzalez, L., and B. F. J. Manly. 1998. Analysis of variance by randomization with small data sets. Environmetrics 9(1):53-65. http://dx.doi.org/10.1002/(SICI)1099-095X(199801/02)9:1<53::AIDENV285>3.0.CO;2-\#

Gould, R. K., S. C. Klain, N. M. Ardoin, T. Satterfield, U. Woodside, N. Hannahs, G. C. Daily, and K. M. Chan. 2015. A protocol for eliciting nonmaterial values using a cultural ecosystem services frame: analyzing cultural ecosystem services. Conservation Biology 29(2):575-586. http://dx.doi.org/10.1111/ cobi.12407

Grothmann, T., and A. Patt. 2005. Adaptive capacity and human cognition: the process of individual adaptation to climate change. Global Environmental Change 15(3):199-213. http://dx.doi. org/10.1016/j.gloenvcha.2005.01.002

Heimlich, J. E., and N. M. Ardoin. 2008. Understanding behavior to understand behavior change: a literature review. Environmental Education Research 14(3):215-237. http://dx.doi. org/10.1080/13504620802148881

Hennon, P. E., D. V. D'Amore, P. G. Schaberg, D. T. Wittwer, and C. S. Shanley. 2012. Shifting climate, altered niche, and a dynamic conservation strategy for yellow-cedar in the North Pacific coastal rainforest. BioScience 62:147-158. http://dx.doi.org/10.1525/ bio.2012.62.2.8

Hennon, P. E., C. M. McKenzie, D. V. D’Amore, D. T. Wittwer, R. L., Mulvey, M. S. Lamb, F. E. Biles, and R. C. Cronn. 2015. A climate adaptation strategy for conservation and management of yellow-cedar in Alaska. General technical report PNW-GTR-917. Department of Agriculture, Forest Service, Pacific Northwest Research Station. Portland, Oregon, USA. [online] URL: http:// www.fs.fed.us/pnw/pubs/pnw gtr917.pdf

Hines, J. M., H. R. Hungerford, and A. N. Tomera. 1987. Analysis and synthesis of research on responsible environmental behavior: a meta-analysis. Journal of Environmental Education 18(2):1-8. http://dx.doi.org/10.1080/00958964.1987.9943482

Kals, E., D. Schumacher, and L. Montada. 1999. Emotional affinity toward nature as a motivational basis to protect nature. Environment and Behavior 31(2):178-202. http://dx.doi. org/10.1177/00139169921972056

Kellert, S. R. 1996. The value of life: biological diversity and human society. Island, Washington, D.C., USA.

Kellert, S. J. 1997. Kinship to mastery: biophilia in human evolution and development. Island, Washington, D.C., USA.

Kellogg, E. L., editor. 1992. Coastal temperate rain forests: ecological characteristics, status and distribution worldwide. Ecotrust, Portland, Oregon, USA.

Kirsch, S. 2001. Lost worlds: environmental disaster, "culture loss," and the law. Current Anthropology 42:167-198. http://dx.doi. org/10.1086/320006
Klain, S. C., T. A. Satterfield, and K. M. A. Chan. 2014. What matters and why? Ecosystem services and their bundled qualities. Ecological Economics 107:310-320. http://dx.doi.org/10.1016/j. ecolecon.2014.09.003

Kollmuss, A., and J. Agyeman. 2002. Mind the gap: why do people act environmentally and what are the barriers to proenvironmental behavior? Environmental Education Research 8 (3):239-260. http://dx.doi.org/10.1080/13504620220145401

Lakoff, G. 2010. Why it matters how we frame the environment. Environmental Communication 4:70-81. http://dx.doi. org/10.1080/17524030903529749

Lamb, M., and L. Winton, editors. 2011. Forest health conditions in Alaska-2010: a forest health protection report. Report no. R10PR-23. U.S. Department of Agriculture, Forest Service, Alaska Region, Anchorage, Alaska, USA. [online] URL: http://www.fs. usda.gov/Internet/FSE DOCUMENTS/stelprdb5292240.pdf

Lambin, E. F., H. J. Geist, and R. R. Rindfuss. 2006. Introduction: local processes with global impacts. Pages 1-8 in E. F. Lambin and H. J. Geist, editors. Land-use and land-cover change. SpringerVerlag, Berlin, Germany. http://dx.doi.org/10.1007/3-540-32202-7_1

Lorenzoni, I., S. A. Nicholson-Cole, and L. Whitmarsh. 2007. Barriers perceived to engaging with climate change among the UK public and their policy implications. Global Environmental Change 17:445-459. http://dx.doi.org/10.1016/j.gloenvcha.2007.01.004

Maxwell, J. A. 2005. Qualitative research design: an interactive approach. Sage, Thousand Oaks, California, USA.

McArdle, B. H., and M. J. Anderson. 2001. Fitting multivariate models to community data: a comment on distance-based redundancy analysis. Ecology 82(1):290-297. http://dx.doi. org/10.1890/0012-9658(2001)082[0290:fmmtcd]2.0.co;2

Moser, S. C. 2014. Communicating adaptation to climate change: the art and science of public engagement when climate change comes home. Wiley Interdisciplinary Reviews: Climate Change 5 (3):337-358. http://dx.doi.org/10.1002/wcc. 276

Norgaard K. M. 2011. Living in denial: climate change, emotions, and everyday life. MIT Press, Cambridge, Massachusetts, USA. http://dx.doi.org/10.7551/mitpress/9780262015448.001.0001

O’Neill, S., and S. Nicholson-Cole. 2009. "Fear won't do it": promoting positive engagement with climate change through visual and iconic representations. Science Communication 30:355-379. http://dx.doi.org/10.1177/1075547008329201

Ostrom, E. 2009. A general framework for analyzing sustainability of social-ecological systems. Science 325:419-422. http://dx.doi.org/10.1126/science.1172133

Otieno, C., H. Spada, K. Lieblar, T. Ludeman, U. Deil, and A. Renk1. 2014. Informing about climate change and invasive species: how the presentation of information affects perceptions of risk, emotions, and learning. Environmental Education Research 20 (5):612-638. http://dx.doi.org/10.1080/13504622.2013.833589

Parry, M. L., O. F. Canziani, J. P. Palutikof, P. J. van der Linden, and C. E. Hanson, editors. 2007. Climate change 2007: impacts, adaptation and vulnerability. Contribution of Working Group II to the Fourth Assessment Report of the Intergovernmental Panel 
on Climate Change. Cambridge University Press, Cambridge, Cambridge, UK. [online] URL: https://www.ipcc.ch/

publications and data/publications ipcc fourth assessment report_wg2_report_impacts_adaptation_and_vulnerability.htm

Patton, M. Q. 2002. Qualitative research and evaluation methods. 3rd edition. Sage, Thousand Oaks, California, USA.

R Development Core Team. 2013. R: a language and environment for statistical computing. R Foundation for Statistical Computing, Vienna, Austria.

Rajecki, D. W. 1982. Attitudes: themes and advances. Sinauer, Sunderland, Massachusetts, USA.

Ramsey, C. E., and R. E. Rickson. 1976. Environmental knowledge and attitudes. Journal of Environmental Education 8 (1):10-18. http://dx.doi.org/10.1080/00958964.1976.9941552

Reser, J. P., and J. K. Swim. 2011. Adapting to and coping with the threat and impacts of climate change. American Psychologist 66(4):277. http://dx.doi.org/10.1037/a0023412

Riedlinger, D., and F. Berkes. 2001. Contributions of traditional knowledge to understanding climate change in the Canadian Arctic. Polar Record 37(203): 315-328. http://dx.doi.org/10.1017/ $\underline{\text { s0032247400017058 }}$

Rogan, R., M. O'Connor, and P. Horwitz. 2005. Nowhere to hide: awareness and perceptions of environmental change, and their influence on relationships with place. Journal of Environmental Psychology 25(2):147-158. http://dx.doi.org/10.1016/j.jenvp.2005.03.001

Rounsevell, M. D. A., B. Pedroli, K.-H. Erb, M. Gramberger, A. G. Busck, H. Haberl, S. Kristensen, T. Kuemmerle, S. Lavorel, M. Lindner, H. Lotze-Campen, M. J. Metzger, D. Murray-Rust, A. Popp, M. Pérez-Soba, A. Reenberg, A. Vadineanu, P. H. Verburg, and B. Wolfslehner. 2012. Challenges for land system science. Land Use Policy 29(4):899-910. http://dx.doi.org/10.1016/ j.landusepol.2012.01.007

Rubinstein, R. I., and P. A. Parmelee. 1992. Attachment to place and the representation of the life course by the elderly. Pages 139-163 in I. Altman and S. M. Low, editors. Place attachment. Springer, New York, New York, USA. http://dx.doi. org/10.1007/978-1-4684-8753-4 7

Russell, R., A. D. Guerry, P. Balvanera, R. K. Gould, X. Basurto, K. M. A. Chan, S. Klain, J. Leving, and J. Tam. 2013. Humans and nature: how knowing and experiencing nature affect wellbeing. Annual Review of Environment and Resources 38 (6):473-502. http://dx.doi.org/10.1146/annurev-environ-012312-110838

Satterfield, T. 2001. In search of value literacy: suggestions for the elicitation of environmental values. Environmental Values 10 (3):331-359. http://dx.doi.org/10.3197/096327101129340868

Scannell, L., and R. Gifford. 2010. Defining place attachment: a tripartite organizing framework. Journal of Environmental Psychology 30(1):1-10. http://dx.doi.org/10.1016/j.jenvp.2009.09.006

Schaberg, P. G., P. E. Hennon, D. V. D’Amore, and G. J. Hawley. 2008. Influence of simulated snow cover on the cold tolerance and freezing injury of yellow-cedars seedlings. Global Change Biology 14:1282-1293. http://dx.doi.org/10.1111/j.1365-2486.2008.01577. $\underline{\mathrm{X}}$
Schaberg, P. G., P. E. Hennon, D. V. D'Amore, G. J. Hawley, and C. H. Borer. 2005. Seasonal differences in freezing tolerance of yellow-cedar and western hemlock trees at a plot affected by yellow-cedar decline. Canadian Journal of Forest Research 35 (8):2065-2070. http://dx.doi.org/10.1139/x05-131

Schaberg, P. G., D. V. D'Amore, P. E. Hennon, J. M. Halman, and G. J. Hawley. 2011. Do limited cold tolerance and shallow depth of roots contribute to yellow-cedar decline? Forest Ecology and Management 262:2142-2150. http://dx.doi.org/10.1016/j. foreco.2011.08.004

Schultz, P. W. 2000. Empathizing with nature: the effect of perspective taking on concern for environmental issues. Journal of Social Issues 56:391-406. http://dx.doi.org/10.1111/0022-4537.00174

Schultz, P. W. 2001. Assessing the structure of environmental concern: concern for self, other people, and the biosphere. Journal of Environmental Psychology 21(4):327-339. http://dx.doi. org/10.1006/jevp.2001.0227

Schultz, P. W. 2002. Inclusion with nature: understanding the psychology of human-nature interactions. Pages 61-78 in P. Schmuck and P. W. Schultz, editors. The psychology of sustainable development. Kluwer, Boston, Massachusetts, USA.

Schultz, P. W., C. Shriver, J. J. Tabanico, and A. M. Khazian. 2004. Implicit connections with nature. Journal of Environmental Psychology 24(1):31-42. http://dx.doi.org/10.1016/s0272-4944 (03)00022-7

Smit, B., and J. Wandel. 2006. Adaptation, adaptive capacity and vulnerability. Global Environmental Change 16(3):282-292. http:// dx.doi.org/10.1016/j.gloenvcha.2006.03.008

Spittlehouse, D. L. 2005. Integrating climate change adaptation into forest management. Forestry Chronicle 81(5):691-695. http:// dx.doi.org/10.5558/tfc81691-5

Stokols, D., and S. A. Shumaker. 1981. People and places: a transactional view of settings. Pages 441-448 in J. H. Harvey, editor. Cognition, social behavior and the environment. Erlbaum, Hillsdale, New Jersey, USA.

Sundblad, E.-L., A. Biel, and T. Gärling. 2009. Knowledge and confidence in knowledge about climate change among experts, journalists, politicians, and laypersons. Environment and Behavior 41(2):281-302. http://dx.doi.org/10.1177/0013916508314998

Swim, J. K., P. C. Stern, T. J. Doherty, S. Clayton, J. P. Reser, E. U. Weber, R. G. Gifford, and G. S. Howard. 2011. Psychology's contributions to understanding and addressing global climate change. American Psychologist 66(4):241-250. http://dx.doi. org/10.1037/a0023220

Trainor, S. F., M. Calef, D. Natcher, F. S. Chapin, III, A. D. McGuire, O. Huntington, P. Duffy, T. S. Rupp, L. DeWilde, M. Kwart, N. Fresco, and A. L. Lovecraft. 2009. Vulnerability and adaptation to climate-related fire impacts in rural and urban interior Alaska. Polar Research 28:100-118. http://dx.doi. org/10.1111/j.1751-8369.2009.00101.x

Turner, B. L., II, E. F. Lambin, and A. Reenberg. 2007. The emergence of land change science for global environmental change and sustainability. Proceedings of the National Academy of Sciences 104(52):20666-20671. http://dx.doi.org/10.1073/ pnas.0704119104 
United States Department of Agriculture - Forest Service (USDA-FS). 2008. Tongass national forest land and resource management plan. Forest Service RM10-MB-603b. United States Department of Agriculture - Forest Service, Alaska Region, Juneau, Alaska, USA. [online] URL: http://www.fs.usda.gov/ land/tongass/landmanagement

United States Department of Agriculture - Forest Service (USDA-FS). 2010. Cumulative yellow-cedar decline. Southeast Alaska GIS Library. United States Department of Agriculture Forest Service, Alaska Region, Juneau, Alaska, USA. http:// seakgis03.alaska.edu/arcgis/rest/services/USFS/USFS_CumulativeYellowCedarDecline/MapServer

Uzzell, D. L. 2000. The psycho-spatial dimension of global environmental problems. Journal of Environmental Psychology 20 (4):307-318. http://dx.doi.org/10.1006/jevp.2000.0175

Vaughan, M. B., and N. M. Ardoin. 2014. The implications of differing tourist/resident perceptions for community-based resource management: a Hawaiian coastal resource area study. Journal of Sustainable Tourism 22(1):50-68. http://dx.doi. org/10.1080/09669582.2013.802326

Vaske, J. J., and K. C. Kobrin. 2001. Place attachment and environmentally responsible behavior. Journal of Environmental Education 32(4):16-21. http://dx.doi.org/10.1080/00958960109598658

Westfall, J., and T. Ebata. 2014. Summary of forest health conditions in British Columbia. Pest Management Report 15. British Columbia Ministry of Forests, Range and Natural Resource Operations, Victoria, British Columbia, Canada. [online] URL: http://www2.gov.bc.ca/assets/gov/environment/ research-monitoring-and-reporting/monitoring/aerial-overview-surveydocuments/2014-fh-bc-overview.pdf

Wibeck, V. 2014. Enhancing learning, communication and public engagement about climate change - some lessons from recent literature. Environmental Education Research 20(3):387-411. http://dx.doi.org/10.1080/13504622.2013.812720

Williams, D. R., and J. W. Roggenbuck. 1989. Measuring place attachment: some preliminary results. Symposium on Outdoor Recreation Planning and Management. NRPA Symposium on Leisure Research, San Antonio, Texas, USA. [online] URL: http://www.fs.fed.us/rm/value/docs/nrpa89.pdf

Williams, D. R., and M. E. Patterson. 1999. Environmental psychology: mapping landscape meanings for ecosystem management. Pages 141-160 in H. K. Cordell and J. C. Bergstrom, editors. Integrating social sciences and ecosystem management: human dimensions in assessment, policy, and management. Sagamore, Champaign, Illinois, USA.

Williams, D. R., and J. J. Vaske. 2003. The measurement of place attachment: validity and generalizability of a psychometric approach. Forest Science 49(6):830-840. [online] URL: $\underline{\text { http:// }}$ www.fs.fed.us/rm/pubs other/rmrs 2003 williams d001.pdf

Wolken, J. M., T. N. Hollingsworth, T. S. Rupp, F. S. Chapin, III, S. F. Trainor, T. M. Barrett, P. K. Sullivan, A. D. McGuire, E. S. Euskirchen, P. E. Hennon, Erik A. Beever, J. S. Conn, L. K. Crone, D. V. D'Amore, N. Fresco, T. A. Hanley, K. Kielland, J. J. Kruse, T. Patterson, E. A. G. Schuur, D. L. Verbyla, and J. Yarie. 2011.
Evidence and implications of recent and projected climate change in Alaska's forest ecosystems. Ecosphere 2(11):1-35. http://dx.doi. org/10.1890/es11-00288.1

Wolf, J., and S. C. Moser. 2011. Individual understandings, perceptions, and engagement with climate change: insights from in-depth studies across the world. Wiley Interdisciplinary Reviews: Climate Change 2:547-569. http://dx.doi.org/10.1002/wcc.120 
Appendix 1 Materials and methods

\section{Study background}

Previous research in southeast Alaska examined the complex dynamics of land-use change, societal feedbacks, and management regimes (Beier et al. 2008). The area's mixed cash-subsistence economy is highly reliant on both extractive (logging, fisheries, and mining) and non-extractive (tourism) uses of natural resources. The increase in regional mean annual temperature between 1948 and 1999 (Stafford et al. 2000) is approximately double that of global mean temperature increase since the mid-20 $0^{\text {th }}$ century (IPCC 2013). This regional trend is associated with warmer winters (Wolken et al. 2011) and precipitation occurring as more rainfall rather than snow (Markon et al. 2012).

People throughout southeast Alaska have long used and valued yellow-cedar trees. For millennia, Native people of the Pacific Northwest have used these trees for clothing, shelter, tools, and transportation, as well as for artistic, ceremonial, and spiritual activities (Stewart 1984). A controversial 50-year boom-bust cycle of industrial logging in the latter $20^{\text {th }}$ century primarily targeted spruce and hemlock species for pulp production (Nie 2006, Beier 2011). Yellow-cedar has since increased in economic value, and currently holds the highest market value of any Alaskan tree species (Beier 2011). Yellow-cedar losses, therefore, may have important ecological, economic, and cultural implications, with resulting human-system responses.

\section{Interview protocol}

We chose an empirical method that allowed us to explore patterns in the sample frame between the knowledge that individuals had already obtained and adaptations they had already adopted to ecological changes that had already occurred. Our semi-structured interview protocol elicited self-reported data, but enabled us to assess processes of adaptation underway in an impacted ecosystem. Alternative methods to our interview approach, such as introducing knowledge of causal mechanisms to those unaware of the dieback in a controlled comparison and studying their responses over time, would have been infeasible in the remote archipelago for participant recruitment and follow-up. Additionally, our narrative interview approach enabled us to explore the web of factors known to motivate environmentally responsible behaviors to examine its relevance to individual adaptation.

Five pilot interviews helped refine the semi-structured interview protocol; two of those pilot interviews that used the final interview protocol were included in the dataset for analyses. We provide the protocol here in its entirety, which was administered verbally.

\section{[Interview begins.]}

\section{Interviewer:}

I'm interested in talking with you about yellow-cedar forests and learning more from your knowledge and experience in this region. I'd just like to start with some more general background questions about you and then we'll delve into deeper conversation. 
These first background questions should go relatively quickly and take 5 to 10 minutes. Then we can spend more time in discussion so that I can understand your perspective on forest issues here in southeast Alaska. I anticipate your involvement will take 1 to 2 hours, but of course, you can decide how much time you'd like to spend.

Your participation in this study is completely voluntary. You are free to decline to participate, to end participation at any time for any reason, or to refuse to answer any individual question. Also, you are free to request deletion of any material from my study records, in written or audio form. With your verbal consent, I will record our discussion together.

[Interviewer reviews confidentiality agreement and obtains consent for participation, according to Stanford University IRB, Protocol \#24164.]

Introduction

Interviewer:

This is an exploration and conversation, and there are no right or wrong answers. Thank you for taking the time to talk with me.

[Interviewer starts the digital recording device.]

Interviewer:

What year were you born and where?

How long have you lived in Alaska? In southeast Alaska? In your current town?

How many years have you been an Alaskan resident?

If you were not born in state, what attracted you to move to Alaska? Can you tell me more about your motivations for moving/coming to Alaska?

Are you currently working, between jobs, or a student?

If you work, what is your occupation?

- [If appropriate]: How did you come to have your position at X organization/company/agency? How did you come to do the work you do?

- [If appropriate]: Can you tell me if and/or why your involvement in X organization/company/agency is important to you?

Do you have any children? Who lives in your household?

Do you participate in subsistence activities? If yes, what kinds of activities? 
In terms of your relationship to Alaska's forests, with which of these groups do you most identify:

- Native Customary and Traditional Use

- Non-Native Subsistence

- Resource Management

- Recreation and Tourism

- Conservation

- Science and Naturalism

- Commercial Logging

- Mixed-Use [Probe: Which of the groups that I just listed describe your mixeduse?]

Do you consider yourself a forest user or manager?

\section{$\underline{\text { Section 1: Background }}$}

Interviewer:

I'm interested in your personal perspective today. I want to learn from your personal experience in southeast Alaska and your knowledge of the forests here.

How would you describe your relationship with coastal forests in southeast Alaska?

Has your interest or involvement in issues related to southeast Alaska's forests changed over time? If so, how?

\section{Section 2: Knowledge}

Interviewer:

I'd like to spend a good bit of time today talking about yellow-cedar forests in particular.

[Note to Interviewer: For clear mutual understanding and interpretation throughout the discussion, the interviewer may need to explore language used early with the interviewee: "yellow-cedar forest" refers to a "forest with yellow-cedar in it."]

Do you distinguish a forest with yellow-cedar trees from other forested areas? In what ways?

What kinds of human activities and natural disturbances do you feel have altered yellowcedar forests specifically in southeast Alaska?

Have you seen forests surrounding your town or in southeast Alaska that appear dead or dying? Could you tell me what's happening to these forests or if there are specific species impacted? [Probe, if appropriate: What's causing these changes you have observed?] 
Are there other changes occurring in southeast Alaska that appear to be altering these yellow-cedar forests? In what ways?

Where do you get information about forests in southeast Alaska?

[Probe, if appropriate: You mentioned yellow-cedar decline, but can you tell me what that means to you? Where do you get information about what may be causing these patches of dead trees?]

Section 3: Healthy Forests, Attachment, and Use Values Derived from Forests Unaffected by the Dieback

Interviewer:

What does a "healthy yellow-cedar forest" mean to you specifically? How would you describe that forest and its ecological community?

In what ways do you value these healthy yellow-cedar forests?

What about old growth and young growth? Do you value a yellow-cedar tree differently based upon its age? If so, in what way(s)?

Do you think of yourself and these yellow-cedar forests as connected in any ways? If so, can you describe that personal link? [Probe: How does that link work? How do you know it exists? How strong is that link?]

In what ways do yellow-cedar forests contribute to your well-being and the well-being of your community? What about their economic contribution?

[Note to Interviewer: Use maps of southeast Alaska and local area to facilitate discussions of specific locations.]

Can you identify some places locally where there are healthy yellow-cedar forests? What activities do you do related to these forests?

Describe for me the ways you have used yellow-cedar forests. [Probe: personal uses versus professional work.]

\section{Section 4: Forests Affected by the Dieback}

Interviewer:

I'd like to focus for a bit on yellow-cedar decline.

[Note to Interviewer: If necessary, based upon previous knowledge exploration, explain the term "yellow-cedar decline" to clarify with "death," "mortality," "patches of dead yellow-cedar trees on the landscape," and/or "dieback."] 
What does "yellow-cedar decline" mean to you specifically? How would you describe the ecological or natural community affected by decline? [Probe, if necessary, with various terms for decline, such as patches of dead yellow-cedar trees or widespread tree death.]

Let's revisit the values you thought about with healthy yellow-cedar forests. Imagine yourself standing in a declining yellow-cedar forest and think about these values.

Does yellow-cedar decline influence how or in what ways you value these forests?

What ways do you value dead yellow-cedar trees?

[Note to Interviewer: Use maps of southeast Alaska and local area to facilitate discussions of specific locations.]

Can you identify some places locally where there are dead yellow-cedars? What activities do you do related to these forests?

Describe for me the ways you have used yellow-cedar forests affected by the dieback. [Probe: personal uses versus professional work.]

Section 5: Attitudes about the Impacts Occurring

\section{Interviewer:}

When you think about yellow-cedar decline and these trees dying, how do you feel about these changes?

Do you consider yellow-cedar decline a forest disturbance? [Probe, if appropriate: In what ways?]

Do you think the process of change the forest undergoes creates other opportunities and resources? [Probe, if appropriate: feelings about changes, if they emerge.]

Do you think the process of change the forest undergoes creates losses? [Probe, if appropriate: feelings about changes, if they emerge.]

\section{Section 6: Experience in Forests (Unaffected versus Affected Forests)}

\section{Interviewer:}

I'd like to talk with you about your experience in these forests. We'll talk about both healthy yellow-cedar forests and also the forests with widespread tree death.

Have you spent time in any of the yellow-cedar forests affected by the dieback? [Note to Interviewer: If "yes," then continue.] 
Are there yellow-cedar forests that are important to you because of what you gain from them? Are these gains different from healthy forests versus those affected by decline?

[Note to Interviewer: If intangible values arise from the participant, probe with follow-up questions.] What do you feel from your experience in a healthy forest and how does that compare to what you feel from your experience in a forest affected by decline? Tell me about the non-material gains.

[Probe, if appropriate: Feel free to use stories about your experiences in these places, if that helps. These can be things specific to you or your family or community. They can be recent or historical.]

Section 7: Comparing Use Values between Forests Unaffected and Forests Affected by the Dieback

\section{Interviewer:}

Do your uses differ between live yellow-cedar trees and dead?

Has yellow-cedar decline altered your use of these forests? If yes, provide some examples of the ways your activities in or around forests affected by decline may differ from your activities in or around healthy or live forests?

What are your thoughts on potentially harvesting dead cedar? Would you support or oppose this practice? For what reasons? [Probe protected areas versus managed lands: What are the trade-offs between harvesting dead, as opposed to live, cedar trees?]

\section{Section 8: Management}

Interviewer:

What types of uses do you prioritize for management of yellow-cedar forests? Have these priorities changed over time? In what ways?

I've heard a lot about "multiple uses" on the Tongass. Can you explain what managing forests for multiple uses means to you?

How do you envision forest management of the Tongass in the future?

When you think about managing yellow-cedar forests in the future, how would you prioritize the uses or values we've discussed?

Are there specific things you think could be done to (better) manage yellow-cedar forests? What are they and why do they matter? Feel free to recommend or think out loud about anything that's important to you. [Probe if necessary, recalling notes taken: You've 
mentioned several issues that ought to be addressed to improve forest management. Can you elaborate on which you feel are most important?]

What are your thoughts on planting yellow-cedar trees? Would you support or oppose this practice? For what reasons? [Probe: protected areas versus managed lands]

Do you think there are management opportunities for dead yellow-cedar forests?

In what ways do you think forests affected by the decline may create new uses for humans, fish, or any wildlife?

\section{Section 9: Conservation}

\section{Interviewer:}

Let's talk about ideas like conservation and sustainability for a bit.

I often hear talk about "sustainability" or "sustainable forest communities." What does sustainability mean to you?

If you think about harvesting trees, how do you consider tree age? What about dead versus live yellow-cedar trees?

How do you think sustainability applies to the values and uses we've discussed?

Do you consider conservation to focus on avoiding harvesting alone, or do conservation priorities include consideration of yellow-cedar decline?

What kinds of conservation interests do you consider important for the Tongass forests?

When you think about yellow-cedar harvests in the future, do you think managers should consider increasing protections, such as limiting harvests where they may be more likely to survive, or shifting or expanding protected areas? Would you support or oppose these practices? For what reasons? [Probe: protected areas versus managed lands.]

$\underline{\text { Section 10: Protected Areas versus Managed Lands }}$

Interviewer:

If you knew the decline was going to spread into other areas in southeast Alaska or north to Glacier Bay National Park, would you want to see yellow-cedar forests managed differently? [Probe: protected areas versus managed lands.]

$\underline{\text { Section 11: Environmental Concern, Outlook, and Nature Connection }}$

Interviewer: 
What is the environmental issue or problem that concerns you most and why?

When you think about the environmental problems that concern you today, where do you place yourself on this scale?

\begin{tabular}{|c|c|c|c|c|}
\hline $\begin{array}{l}\text { There is } \\
\text { nothing we } \\
\text { can do. }\end{array}$ & $\begin{array}{c}\text { There is very } \\
\text { little we can } \\
\text { do. }\end{array}$ & $\begin{array}{l}\text { I don't know } \\
\text { if there's } \\
\text { anything we }\end{array}$ & $\begin{array}{c}\text { There are } \\
\text { some things } \\
\text { we can do. }\end{array}$ & $\begin{array}{l}\text { There are a } \\
\text { lot of things } \\
\text { we can do. }\end{array}$ \\
\hline
\end{tabular}

Please circle the picture below that best describes your relationship with the natural environment. How interconnected are you with nature? (Schultz 2001) Would you explain your choice to me?
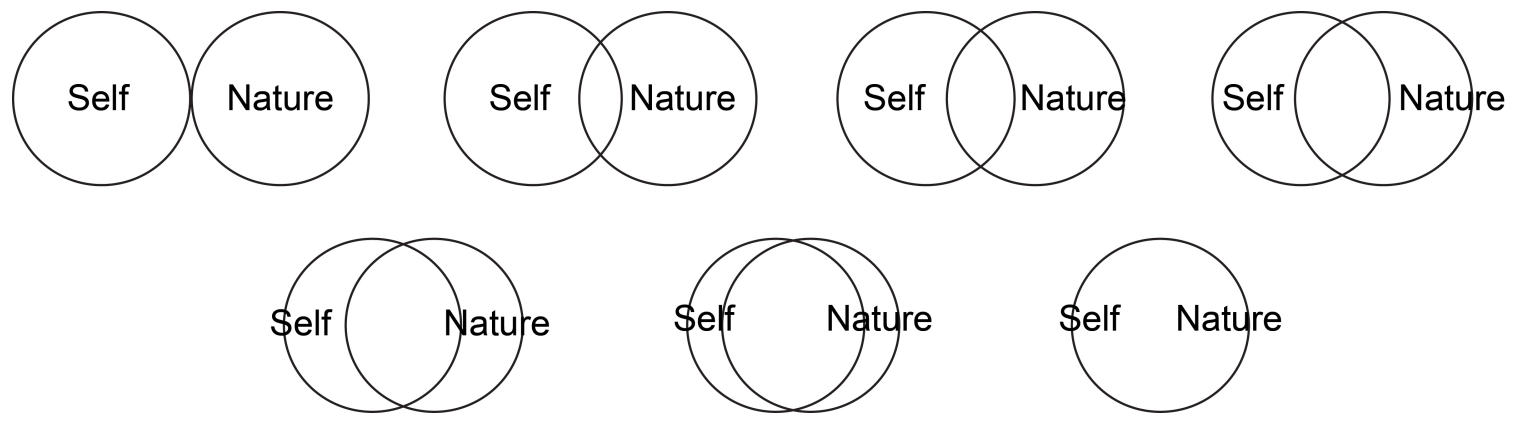

Closing

\section{Interviewer:}

Thank you so much for your time. Those are all the questions I have for you. Do you have any questions for me?

[Note to Interviewer: Provide interviewee with contact information according to approved IRB Protocol.]

\section{Sample frame and characteristics}

All pre-identified forest managers identified themselves as managers, together with three interviewees employed in the non-profit conservation sector. Interviewees self-identified with the pre-assigned participant categories, but many also identified with additional groupings, such as recreation and tourism, conservation, sport hunting, and non-Native residents engaging in subsistence activities. We maintained our stratification of users and managers based upon our definition of managers (i.e., individuals working within the Tongass governance system or managing Alaska Native land) in subsequent analyses.

\section{Data analysis}


In addition to the methods described for analyzing knowledge, we used a priori and emergent coding for explanatory variables: learning, attitudes, attachment, and use values. We used a priori coding for "active" learners (Fonseca and Chi, 2011), who gained knowledge of the causal mechanisms through direct, place-based learning and let other, indirect learning processes emerge (e.g., acquiring information through social channels, such as news media, published studies, or community members). "Concern," "lack of self-efficacy," "pragmatic," and "utilitarian" were used as a priori codes for attitudes (Schultz 2001, Moser 2014, Kellert 1996); others emerged from the interviewees.

A distinction between functional and emotional attachment was determined a priori, but scales of attachment (i.e., southeast Alaska, forest ecosystem, and species) emerged from the data. One example of content coded for emotional attachment at the fine-scale species-level follows: “...Also, it turns out that yellow-cedar is one of my favorite conifers. So why am I kind of drawn to them? I still always enjoy going to South Pass or North Pass, going towards the coast. That's where you kind of enter the real perennial yellow cedar country. It has certain smells to it...I seem to be kind of in love with the yellow cedar. They feel soft. They look kind of sleepy, and they smell good." In contrast, an example of content coded as functional attachment at the species-level includes: "My business relies upon the forest... and yellow-cedar is a big part of that." Also: "It is very much a specific tree. Unfortunately for us, it's not common. The timber is worth twice as much as others, in general."

For use values, we identified a priori themes from our review of regional forest management documents (USDA Forest Service 2008): customary and traditional, education, economic, forest products and personal, recreation, ecological, and sport hunting and gathering. In our results, we report additional themes of use values that emerged from the data, along with the emergent distinction between direct use values and intangible values that interviewees derived from the forests both affected and unaffected by the dieback.

\section{Literature Cited in Appendix 1}

Beier, C. M., T. M. Patterson, and F. S. Chapin III. 2008. Ecosystem services and emergent vulnerability in managed ecosystems: a geospatial decision-support tool. Ecosystems 11(6):923-938.

Beier, C. M. 2011. Factors influencing adaptive capacity in the reorganization of forest management in Alaska. Ecology and Society 16(1):40.

Fonseca, B., and M. T. H. Chi. 2011. Instruction based on self-explanation. Pages 296321 in R. A. Mayer and P. A. Alexander, editors. The handbook of research on learning and instruction. Routledge Taylor and Frances Group, New York, New York, USA.

IPCC 2013 Summary for Policymakers. Climate Change 2013: The Physical Science Basis. Cambridge University Press, Cambridge, United Kingdom, and New York, New York, USA. 
Kellert, S. R. 1996. The value of life: biological diversity and human society. Island Press, Washington, DC, USA.

Markon, C. J., S. F. Trainor, and F. S. Chapin, III, editors. 2012. The United States National Climate Assessment: Alaska. Technical Regional Report: U.S. Geological Survey Circular 1379. U.S. Geological Survey, Reston, VA, USA.

Moser, S. C. 2014. Communicating adaptation to climate change: the art and science of public engagement when climate change comes home. Wiley Interdisciplinary Reviews: Climate Change 5(3):337-358.

Nie, M. 2006. Governing the Tongass: National forest conflict and political decision making. Environmental Law 36:385-480.

Schultz, P. W. 2001. Assessing the structure of environmental concern: concern for self, other people, and the biosphere. Journal of Environmental Psychology 21(4):327-339.

Stafford, J. M., G. Wendler, and J. Curtis. 2000. Temperature and precipitation of Alaska: 50 year trend analysis. Theoretical and Applied Climatology 67(1-2):33-44.

Stewart, H. 1984. Cedar: tree of life to the Northwest Coast Indians. University of Washington Press, Seattle, WA, USA.

USDA Forest Service. 2008. Tongass National Forest Land and Resource Management Plan. Forest Service RM10-MB-603b, Alaska Region, Juneau, AK, USA.

Wolken, J. M., T. N. Hollingsworth, T. S. Rupp, F. S. Chapin III, S. F. Trainor, T. M. Barrett, P. K. Sullivan, A. D. McGuire, E. S. Euskirchen, P. E. Hennon, E. A. Beever, J. S. Conn, L. K. Crone, D. V. D’Amore, N. Fresco, T. A. Hanley, K. Kielland, J. J. Kruse, T. Patterson, E. A. G. Schuur, D. L. Verbyla, and J. Yarie. 2011. Evidence and implications of recent and projected climate change in Alaska's forest ecosystems. Ecosphere 2(11):124. 